\title{
PENGARUH PERTUMBUHAN PENDAPATAN, UKURAN PERUSAHAAN, LEVERAGE, DAN KOMPENSASI KERUGIAN TERHADAP BOOK TAX GAP PADA PERUSAHAAN MANUFAKTUR YANG TERDAFTAR DI BURSA EFEK INDONESIA PERIODE 2014-2018 \\ Muliani Mangngalla' ${ }^{1}$, Luther Palembangan Tangdialla2, Carolus Askikarno Palalangan ${ }^{3}$ \\ Universitas Kristen Indonesia Paulus \\ mulianimangngalla9@gmail.com
}

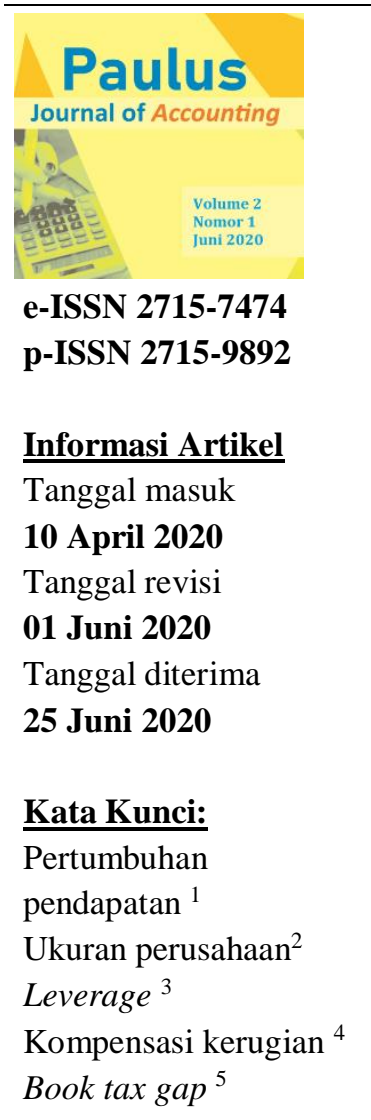

\begin{abstract}
Abstrak: Penelitian ini bertujuan untuk mengetahui pengaruh pertumbuhan pendapatan, ukuran perusahaan, leverage, dan kompensasi kerugian terhadap book tax gap. Objek yang diteliti dalam penelitian ini adalah perusahaan manufaktur yang terdaftar di Bursa Efek Indonesia periode 2014-2018. Metode yang digunakan dalam penelitian ini adalah metode analisis regresi dengan menggunakan pendekatan kuantitatif. Sampel penelitian dipilih dengan teknik purposive sampling dan diperoleh 380 data pengamatan. Penelitian ini menggunakan data sekunder yang diperoleh dari website Bursa Efek Indonesia (www.idx.co.id). Hasil dari penelitian ini menunjukkan bahwa secara simultan dan parsial pertumbuhan pendapatan, ukuran perusahaan, leverage, dan kompensasi kerugian berpengaruh terhadap book tax gap. Variabel pertumbuhan pendapatan dan leverage berpengaruh secara positif sedangkan variabel ukuran perusahaan dan kompensasi kerugian berpengaruh secara negatif terhadap book tax gap.

Abstract: This study aims to determine the effect of revenue growth, company size, leverage, and loss compensation to the tax gap book. The objects published in this study are companies listed on the Indonesia Stock Exchange in 20142018. The method used in this study is a regression analysis method using quantitative. The research sample was selected by purposive sampling technique and 380 data collection were obtained. This study uses secondary data obtained from the Indonesia Stock Exchange website (www.idx.co.id). The results of this study indicate that simultaneous and partial income growth, company size, leverage, and financial compensation towards the book tax gap. Variable income growth and leverage have a positive effect on company size variables and income compensation on the book tax gap.
\end{abstract}

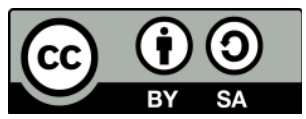

\section{PENDAHULUAN}

Pajak merupakan sumber utama penerimaan untuk mendanai APBN Indonesia. Peraturan pemungutan pajak di Indonesia diatur dalam Undang-undang Nomor 28 Tahun 2007 tentang Ketentuan Umum Perpajakan. Defenisi Pajak menurut Undang-undang Nomor 16 tahun 2009 tentang perubahan keempat atas Undang-undang Nomor 6 tahun 1983 Ketentuan Umum dan Tata Cara Perpajakan pada pasal 1 ayat 1 berbunyi pajak adalah kontribusi wajib kepada negara yang terutang oleh orang pribadi atau badan yang 
bersifat memaksa berdasarkan Undang-Undang, dengan tidak mendapatkan imbalan secara langsung dan digunakan untuk keperluan negara bagi sebesar-besarnya kemakmuran rakyat. Badan usaha baik itu perseroan terbatas, perseroan komanditer, firma maupun BUMN/BUMD merupakan salah satu wajib pajak yang berkewajiban untuk membayar pajak.

Perhitungan laba perusahaan pada setiap periode memiliki dua tujuan pelaporan yaitu tujuan pelaporan keuangan (financial reporting) dan penetapan kewajiban pajak (tax liabilities). (Martani dan Persada, 2010). Laba untuk tujuan akuntansi (pelaporan keuangan) disusun dengan mengacu pada aturan/standar akuntansi yaitu atas dasar akrual kecuali laporan arus kas berdasarkan PSAK No. 1 sedangkan laba untuk tujuan fiskal diatur oleh peraturan pajak berdasarkan pasal 28 UU No. 28 Tahun 2007, perusahaan menyelenggarakan pembukuan menggunakan stelsel akrual atau kas (Mardohar dan Ely, 2016). Ketentuan dan konsep serta tujuan yang berbeda antara SAK dan undang-undang akan menimbulkan perbedaan perhitungan laba. Perbedaan perhitungan laba kedua laporan keuangan tersebut akan menimbulkan perbedaan pajak yang dikenal dengan istilah Book Tax Gap (BTG) (Martani et al., 2011).

Secara umum ada 2 tipe perbedaan yang dapat menyebabkan terjadinya Book Tax Gap yaitu perbedaan yang bersifat permanen dan perbedaan yang bersifat temporer. Perbedaan yang bersifat permanen timbul karena tidak semua pendapatan ataupun biaya yang diakui menurut akuntansi (komerisal) juga diakui menurut pajak (fiskal). Sedangkan, perbedaan sementara atau temporer terjadi akibat dari perbedaan waktu pengakuan pendapatan ataupun biaya dalam menghitung jumlah laba. Pendapat yang sama dikemukakan oleh Mardonar dan Ely (2016) bahwa perbedaan sementara atau perbedaan waktu terjadi karena perbedaan waktu pengakuan pendapatan dan biaya dalam menghitung laba. Suatu biaya atau penghasilan telah diakui menurut fiskal dan belum diakui menurut akuntansi komersial atau sebaliknya. Perbedaan ini bersifat sementara atau temporer karena akan tertutup pada periode sesudahnya.

BTG dapat dipengaruhi oleh beberapa hal yang pada penelitian ini hanya menguji beberapa faktor yang telah dianggap dapat memicu terjadinya produktif praktek manajemen yang akan berpengaruh terhadap book tax gap secara langsung yang dapat menyediakan informasi mengenai kualitas laba serta manfaat yang dapat digunakan untuk mengevaluasi kinerja suatu perusahaan, seperti pertumbuhan pendapatan, ukuran perusahaan, leverage, dan kompensasi kerugian. Penelitian ini meninjau kembali beberapa penelitian yang telah dilakukan oleh peneliti sebelumnya seperti yang dilakukan oleh Irfan dan Endang (2013), mengatakan bahwa pertumbuhan pendapatan berpengaruh positif terhadap book tax gap dan penelitian yang dilakukan oleh Martani dan Persada (2010) yang menyatakan bahwa adanya pengaruh kompensasi kerugian dan ukuran perusahaan terhadap book tax gap.

Berdasarkan uraian diatas peneliti tertarik untuk melakukan penelitian tentang book tax gap dengan judul "Pengaruh Pertumbuhan Pendapatan,Ukuran Perusahaan, Leverage, dan Kompensasi Kerugian Terhadap Book Tax Gap pada Perusahaan Manufaktur yang Terdaftar di BEI “ 


\section{KAJIAN LITERATUR}

\section{Teori Keangenan (Agency Teory)}

Teori agensi ini pertama kali dicetuskan pada tahun 1976 oleh Jensen dan Meckling yang menyatakan bahwa "Hubungan keagenan sebagai kontrak di mana satu atau lebih orang (prinsipal) melibatkan orang lain (agen) untuk melakukan beberapa layanan atas nama mereka yang melibatkan pendelegasian wewenang pengambilan keputusan kepada agen". Informasi mengenai penghasilan kena pajak atau laba fiskal dapat dilihat dalam catatan atas laporan keuangan oleh pihak prinsipal untuk mendeteksi adanya kecurangan penyajian laporan keuangan yang tidak sesuai dengan PSAK 1 maupun UU perpajakan (Yuli, 2015). Menurut Martani dan Persada (2010), jika publik menduga bahwa angka laba yang ada dalam laporan keuangan perusahaan merupakan hasil rekayasa dari manajemen, maka dalam angka laba dalam laporan keuangan tersebut dinilai kurang persisten bahkan memiliki kualitas laba yang lebih rendah.

\section{Perumusan Hipotesis}

\section{Pengaruh Pertumbuhan Pendapatan Terhadap Book Tax Gap}

Perubahan pendapatan merupakan proksi atas pertumbuhan ekonomi. Pertumbuhan ekonomi tersebut diharapkan akan menghasilkan kenaikan pada piutang, sehingga cadangan kerugian piutang akan bertambah dan menyebabkan selisih yang semakin besar antara laba akuntansi dengan laba fiskal (Irfan dan Endang, 2013). Pertumbuhan ekonomi juga merupakan salah satu faktor kunci dalam memprediksi model akrual yang mengakibatkan perbedaan waktu pengakuan pendapatan antara akuntansi keuangan dengan perpajakan. Penelitian yang dilakukan oleh Irfan dan Endang, 2013 menyatakan bahwa pertumbuhan pendapatan berpengaruh terhadap book tax gap. Berdasarkan penelitian diatas mengenai perumbuhan pendapatan terhadap book tax gap, maka penelitian ini mengajukan hipotesis, yaitu:

\section{H1 : Pertumbuhan pendapatan berpengaruh positif dan signifikan terhadap} book tax gap.

\section{Pengaruh Ukuran Perusahaan Terhadap Book Tax Gap}

Variabel ukuran perusahaan diukur dengan menggunakan proksi total asset karena perusahaan dengan ukuran besar akan lebih efektif dalam berinvestasi pada asset yang memberikan manfaat pajak (Irfan dan Endang, 2013).Ukuran perusahaan dianggap menghasilkan gangguan pada book tax gap, karena semakin besar ukuran perusahaan maka dapat melakukan tax planning dengan baik (Irfan dan Endang, 2013). Penelitian yang dilakukan Martani dan Persada (2010) dan Yuli (2015menyatakan bahwa ukuran perusahaan berpengaruh terhadap book tax gap. Berdasarkan penelitian diatas mengenai ukuran perusahaan terhadap book tax gap, maka penelitian ini mengajukan hipotesis, yaitu:

H2: Ukuran perusahaan berpengaruh negatif dan signifikan terhadap book tax gap.

Pengaruh Leverage (Tingkat Utang) Terhadap Book Tax Gap 
Utang akan menimbulkan beban tetap (fixed rateof return) yang disebut dengan bunga. Semakin besarutang maka laba kena pajak akan menjadi lebih kecil karena insentif pajak atas bunga utang semakin besar. Hal tersebut membawa implikasi meningkatnya penggunaan utang oleh perusahaan. Penelitian Taylor dan Richardson (2013), memberikan bukti bahwa perusahaan yang memiliki kewajiban pajak tinggi akan memilih untuk berutang agar mengurangi pajak.

Penelitian yang dilakukan oleh Ikhsan dan Rahmawaty (2017), menyatakan bahwa leverage berpengaruh terhadap book tax gap. Berdasarkan penelitian diatas mengenai leverage terhadap book tax gap, maka penelitian ini mengajukan hipotesis, yaitu:

\section{H3: Leverage berpengaruh positif dan signifikan terhadap book tax gap.}

\section{Pengaruh Kompensasi Kerugian Terhadap Book Tax Gap}

Kompensai kerugian (KOP) adalah nilai rugi akuntansi masa lalu yang dimanfaatkan pada periode sekarang. Kompensasi kerugian dihitung dari nilai rugi operasi yang dimanfaatkan pada periode pelaporan ini dibagi total aset (Martani dan Persada, 2010). Nilai Kompensasi kerugian yang tejadi selama periode 5 tahun berturutturut menurut peraturan perpajakan dapat dimanfaatkan emiten sebagai pengurang penghasilan kena pajak, sedangkan menutut Standar Akuntansi Keuangan tidak dapat dikurangkan. Penelitian yang dilakukan oleh Martani dan Persada dan Yuli (2015), menyatakan bahwa kompensasi kerugian berpengaruh terhadap book tax gap. Berdasarkan penelitian diatas mengenai kompensasi kerugian terhadap book tax gap, maka penelitian ini mengajukan hipotesis, yaitu:

\section{H4: Kompensasi berpengaruh negatif dan signifikan terhadap book tax gap.}

\section{METODE PENELITIAN}

Penelitian ini merupakan jenis pendekatan kuantitatif. Penelitian kuantitatif merupakan jenis penelitian yang menekankan pada pengujian terhadap teori-teori dengan mengukur variabel-variabel penelitian menggunakan angka dan melakukan analisis terhadap data menggunakan prosedur statistik (Deni, 2014). Populasi yang digunakan dalam riset ini, yaitu semua perusahaan manufaktur yang listed di Bursa Efek Indonesia (BEI) pada periode tahun 2014-2018.

Dalam penelitian ini teknik pemilihan sampel yang digunakan adalah metode purposive sampling. Adapun yang dimaksud dengan purposive sampling, yaitu salah satu metode pemilihan sampel non probabilita yang menggunakan kriteria-kriteria yang telah ditetapkan dan dipertimbangkan sebelumnya oleh peneliti sebagai dasar pengambilan sampel penelitian (Sugiyono, 2011). Penelitian ini menggunakan jenis data sekunder yang diperoleh dari Bursa Efek Indonesia, IDX Statistic, www.idx.co.id. Penelitian ini menggunakan teknik pengumpulan data berupa riset kepustakaan atau Library Research, serta metode dokumentasi.

Pertumbuhan pendapatan, ukuran perusahaan, leverage, dan kompensasi kerugian merupakan variabel independen penelitian ini. Pertumbuhan Pendapatan merupakan proksi pertumbuhan dihitung dari selisih antara penjualan saat ini dengan penjualan $(t)$ 
bersih tahun sebelumnya (t-kemudian dibagi total aset (Irfan dan Endang, 2013). Ukuran perusahaan (SIZE) dapat diketahui dengan dari logaritma natural terhadap total aktiva/aset perusahaan (Irfan dan Endang, 2013). Leverage diukur dengan membandingkan total utang dengan total modal (Riansa dan Rahmawati, 2017)

Kompensasi rugi fiskal merupakan proses peralihan kerugian dari satu periode ke periode berikutnyayang menunjukkan perusahaan yang sedang merugi dan tidak akan dibebani pajak, dapat diukur dengan menggunakan variabel dummy. Nilai 1 jika terdapat kompensasi rugi fiskal pada awal tahun $t$ dan jinilai 0 jika tidak terdapat kompensasi rugi fiskal pada awal tahun t. (Persada dan Martani, 2010).

Sementara itu, variabel terikat (dependen) pada penelitian ini adalah book tax gap. Book tax gap merupakan selisih antara laba akuntansi denga laba pajak kemudian dibagi dengan total aset, (Martani et al., 2011).

Teknik analisis data yang digunakan dalam penelitian ini adalah analisis regresi linear berganda dirumuskan sebagai berikut:

$$
\mathrm{Y}=\alpha+\beta 1 X 1 \beta 2 \mathrm{X} 2+\beta 3 X 3+\beta 3 X 4+e
$$

di mana:

$$
\begin{array}{ll}
\mathrm{Y} & =\text { Book Tax Gap } \\
\alpha & =\text { Konstanta } \\
\beta 1-\beta 4 & =\text { Koefisien regresi dari setiap variabel independen } \\
\mathrm{X} 1 & =\text { Pertumbuhan penjualan } \\
\mathrm{X} 2 & =\text { Ukuran Perusahaan } \\
\mathrm{X} 3 & =\text { Leverage } \\
\mathrm{X} 4 & =\text { Kompensasi Kerugian } \\
e & =\text { errors terms }
\end{array}
$$

\section{HASIL DAN PEMBAHASAN}

Penelitian ini menggunakan sampel perusahaan manufaktur yang terdaftar di Bursa Efek Indonesia tahun 2014 - 2018. Dengan menggunakan pendekatan purposive sampling, sehingga diperoleh sampel sebanyak 82 data pengamatan.

\section{Pengujian dan Hasil Analisis Data}

\section{Pengujian Parsial (Uji T)}

Pengujian ini bertujuan untuk mengetahui seberapa jauh pengaruh satu variabel independen secara individual dalam menerangkan variasi variabel dependen.

Tabel 4.2

Hasil Uji Signifikansi (T)

\begin{tabular}{|c|c|c|c|}
\hline Variabel & t-Tabel & t-Hitung & Sig \\
\hline Pertumbuhan Pendapatan & 1.966 & 38.343 & 0,000 \\
\hline Ukuran Perusahaan & 1.966 & -12.338 & 0,000 \\
\hline Leverage & 1.966 & 44.626 & 0,000 \\
\hline Kompensasi Kerugian & 1.966 & -2.024 & 0,044 \\
\hline
\end{tabular}

Sumber: Data yang diolah peneliti 
Berdasarkan hasil perhitungan uji t diperoleh nilai t-tabel sebesar 1.966 dan t-hitung pertumbuhan pendapatan 38.343 dengan signifikansi 0.000 . Dengan demikian H1 diterima.

$\mathrm{H}_{1}$ : Pertumbuhan Pendapatan berpengaruh positif dan signifikan terhadap book tax gap

Dari pengujian uji t diperoleh nilai t-tabel sebesar 1.966 dan t-hitung ukuran perusahaan -12.338 dengan signifikansi 0.000. Dengan demikian H2 diterima.

$\mathrm{H}_{2}$ : Ukuran Perusahaan berpengaruh negatif dan signifikan terhadap book tax gap Tabel diatas uji $\mathrm{t}$ diperoleh nilai t-tabel sebesar 1.966 dan thitung leverage 44.626 dengan signifikansi 0.000. Dengan demikian H3 diterima.

$\mathrm{H}_{3}$ : Leverage berpengaruh positif dan signifikan terhadap book tax gap.

Dari pengujian uji $\mathrm{t}$ diperoleh nilai t-tabel sebesar 1.966 dan t-hitung kompensasi kerugian -2.024 dengan signifikansi 0.044, karena. Dengan demikian H4 diterima.

$\mathrm{H}_{4}$ : Ukuran Perusahaan berpengaruh negatif dan signifikan terhadap book tax gap.

\section{Analisis Regresi Berganda}

Analisis regresi digunakan untuk mengukur kekuatan hubungan antara dua variabel atau lebih. Dari hasil output, dapat dilihat persamaan regresi linier berganda sebagai berikut:

Tabel 4.4

Hasil Uji Regresi Linear Berganda

\begin{tabular}{|l|c|c|c|c|}
\hline \multicolumn{1}{|c|}{ Variabel } & B & t-Hitung & Sig. & Kesimpulan \\
\hline Pertumbuhan Pendapatan & 0.177 & 38.343 & 0.000 & $\mathrm{H}_{1}$ diterima \\
\hline Ukuran Perusahaan & -0.001 & -12.338 & 0.000 & $\mathrm{H}_{2}$ diterima \\
\hline Leverage & 0.030 & 44.626 & 0.000 & $\mathrm{H}_{3}$ diterima \\
\hline Kompensasi Kerugian & -0.001 & -2.024 & 0.044 & $\mathrm{H}_{4}$ diterima \\
\hline Konstanta $(\alpha)=0.012$ & & \\
\hline $\mathrm{r}^{2}=0.990$ \\
\hline F hitung $=9155.198$
\end{tabular}

Sumber: Data yang diolah peneliti

Berdasarkan hasil regresi pada tabel di atas, persamaan regresi linier berganda dalam penelitian ini dapat dituliskan sebagai berikut:

$$
\mathrm{Y}=0,012+0,177 \mathrm{X}_{1}-0,001 \mathrm{X}_{2}+0,030 \mathrm{X}_{3}-0,001 \mathrm{X}_{4}
$$

Dari persamaan regresi yang telah disusun dapat diinterpretasikan sebagai berikut:

1. Nilai konstanta $(a)$ sebesar 0,012 menunjukkan bahwa apabila variabel independen bernilai konstan, maka nilai book tax gap sebesar 0,012\%.

2. Koefisien pertumbuhan pendapatan sebesar 0,177 menunjukkan bahwa setiap penambahan pertumbuhan pendapatan sebesar $1 \%$ akan diikuti oleh penambahan nilai book tax gap sebesar $0,177 \%$.

3. Koefisien ukuran perusahaan sebesar - 0,001 menunjukkan bahwa setiap penambahan ukuran perusahaan sebesar $1 \%$ akan diikuti oleh penurunan nilai book tax gap sebesar $0,001 \%$. 
4. Koefisien leverage sebesar 0,030 menunjukkan bahwa setiap penambahan leverage sebesar $1 \%$ akan diikuti oleh penambahan book tax gap sebesar $0,030 \%$

5. Koefisien kompensasi kerugian sebesar $-0,001$ menunjukkan bahwa setiap penambahan kompensasi kerugian sebesar $1 \%$ akan diikuti oleh penambahan nilai book tax gap sebesar 0,001\%.

\section{Uji F (Simultan)}

Uji F ini dilakukan untuk menguji apakah model yang digunakan dalam penelitian ini adalah model yang layak ( $f i t$ ) atau tidak.

Tabel 4.5

Uji Signifikan Simultan (Uji Statistik F)

ANOVA $^{\mathrm{a}}$

\begin{tabular}{|ll|r|r|r|r|r|}
\hline Model & & Sum of Squares & df & Mean Square & F & Sig. \\
\hline 1 & Regression & .568 & 4 & .142 & 9155.198 & $.000^{\mathrm{b}}$ \\
& Residual & .006 & 375 & .000 & & \\
& Total & .574 & 379 & & & \\
\hline
\end{tabular}

a. Dependent Variable: Book Tax Gap

b. Predictors: (Constant), Kompensasi Kerugian, Pertumbuhan Pendapatan, Ukuran Perusahaan,

Leverage

Sumber: Data yang diolah peneliti (output SPSS 23)

Pada tabel di atas menunjukkan bahwa nilai $\mathrm{F}$ sebesar 9155.198 dengan nilai signifikansi sebesar $0,000<0,05$. Oleh karena itu model regresi yang digunakan dalam penelitian ini diterima. Sehingga model regresi dalam penelitian ini layak digunakan untuk pengujian dengan model regresi berganda.

\section{Uji Koefisien Determinasi $\left(\mathbf{R}^{\mathbf{2}}\right)$}

Koefisien determinasi $\left(\mathrm{R}^{2}\right)$ pada intinya mengukur seberapa jauh kemampuan model dalam menerangkan variasi variabel dependen. Hasil uji koefisien determinasi dapat dilihat dari tabel di bawah ini.

Tabel 4.14

Uji Koefisien Determinasi

Model Summary ${ }^{b}$

\begin{tabular}{|l|r|r|r|c|}
\hline Model & R & R Square & \multicolumn{1}{c|}{$\begin{array}{c}\text { Adjusted R } \\
\text { Square }\end{array}$} & $\begin{array}{c}\text { Std. Error of the } \\
\text { Estimate }\end{array}$ \\
\hline 1 & $.995^{\mathrm{a}}$ & .990 & .990 & .00393898 \\
\hline
\end{tabular}

a. Predictors: (Constant), Kompensasi Kerugian, Pertumbuhan Pendapatan, Ukuran

Perusahaan, Leverage

b. Dependent Variable: Book Tax Gap

Sumber: Data yang diolah peneliti (output SPSS 23)

Berdasarkan tabel diatas diketahui bahwa koefisien determinasi Adjusted $R$ Square diperoleh hasil sebesar 0,990 atau 99\%. Hasil ini berarti bahwa 99\% variasi book tax gap dapat dijelaskan oleh variabel pertumbuhan pendapatan, ukuran perusahaan, leverage, dan kompensasi kerugian, sedangkan sisanya yaitu $1 \%$ dijelaskan oleh variabel lain diluar model yang diteliti. 


\section{Pembahasan Hasil Analisis Data}

\section{Pengaruh Pertumbuhan Pendapatan terhadap Book Tax Gap}

Dari perhitungan uji t diperoleh nilai t-tabel sebesar 1.966 dan t-hitung 38.343 dengan signifikansi 0.000. Nilai signifikasi tersebut lebih kecil dari 0.05 ini berarti bahwa variabel pertumbuhan pendapatan memiliki pengaruh yang signifikkan terhadap book tax gap. Dengan demikian H1 diterima. Hal ini konsisten dengan Fatkhur dan Endang (2013), yang menyatakan bahwa perubahan pendapatan berpengaruh positif terhadap book tax gap. Pertumbuhan ekonomi diharapkan akan menghasilkan kenaikan pada piutang, sehingga cadangan kerugian piutang akan bertambah dan menyebabkan selisih yang semakin besar antara laba akuntansi dengan laba fiskal. Pertumbuhan ekonomi juga merupakan salah satu faktor kunci dalam memprediksi model akrual yang mengakibatkan perbedaan waktu pengakuan pendapatan antara akuntansi keuangan dengan perpajakan. Proses akrual tersebut menyebabkan selisih yang semakin besar antara laba akuntansi dengan laba fiskal.

\section{Pengaruh Ukuran Perusahaan terhadap Book Tax Gap}

Dari pengujian uji t diperoleh nilai t-tabel sebesar 1.966 dan t-hitung -12.338 dengan signifikansi 0.000 , karena Nilai signifikasi tersebut kurang dari 0.05 , ini berarti bahwa variabel ukuran perusahaan memiliki pengaruh yang signifikan dan negatif terhadap book tax gap. Dengan demikian H2 diterima. Hal ini konsisten dengan penelitian yang dilakukan oleh Jovita (2015) yang menyatakan pengaruh ukuran perusahaan terhadap book tax gap adalah negatif. Hal ini karena semakin besar ukuran perusahaan, akan semakin baik perusahaan dalam melakukan tax planning. Apabila perusahaan melakukan tax planning maka penghasilan kena pajak akan kecil dibandingkan dengan laba sebelum pajak.

\section{Pengaruh Leverage terhadap Book Tax Gap}

Dari uji $\mathrm{t}$ diperoleh nilai t-tabel sebesar 1.966 dan t-hitung 44.626 dengan signifikansi 0.000, karena nilai signifikasi tersebut kurang dari 0.05, ini berarti bahwa variabel leverage memiliki pengaruh yang terhadap book tax gap. Dengan demikian H3 diterima. Hasil penelitian ini mendukung penelitian Ikhsan dan Rahmawaty (2017), yang menyebutkan bahwa tingkat utang pengaruh signifikan terhadap BTG. Leverage merupakan rasio yang menunjukkan seberapa banyak perusahaan menggunakan utang untuk membiayai investasinya. Perusahaan yang memilih pembiayaan utang bukan pembiayaan ekuitas untuk membiayai kegiatan operasinya akan memiliki book tax gap yang rendah dibandingkan dengan pembiayaan ekuitas. Hal ini karena efek bunga yang berasal dari pembiayaan utang tidak dapat dikurangkan dari penghasilan kena pajak.

\section{Pengaruh Kompensasi Kerugian terhadap Book Tax Gap}

Dari pengujian uji t diperoleh nilai t-tabel sebesar 1.966 dan t-hitung -2.024 dengan signifikansi 0.044 , karena nilai signifikasi tersebut kurang dari 0.05 , ini berarti bahwa variabel kompensasi kerugian memiliki pengaruh yang signifikan dan negatif terhadap book tax gap. Dengan demikian H4 diterima. Hasil tersebut sejalan dengan penelitian yang dilakukan oleh Yuli Winarsih (2015) yang menyatakan bahwa kompensasi kerugian berpengaruh terhadap book tax gap. Kompensasi kerugian yang 
dimanfaatkan pada satu periode mengurangi penghasilan kena pajak sehingga selisih penghasilan kena pajak dengan laba akuntansi akan semakin besar.

\section{KESIMPULAN}

1. Pertumbuhan pendapatan, ukuran perusahaan, leverage, dan kompensasi kerugian secara bersama-sama (simultan) berpengaruh terhadap variabel book tax gap.

2. Hasil uji hipotesis secara parsial menunjukkan bahwa:

Pertumbuhan pendapatan menghasilkan nilai signifikan 0,000, dimana nilai tersebut lebih kecil dari 0,05 yang menggambarkan bahwa pertumbuhan pendapatan berpengaruh positif dan signifikan terhadap book tax gap pada perusahaan yang terdaftar di Bursa Efek Indonesia tahun 2014-2018, hal ini karena pendapatan yang terus bertumbuh akan menimbulkan piutang, yang mana menurut Standar Akuntansi Keuangan cadangan kerugian piutang merupakan biaya pengurang penghasilan bruto yang dapat mengurangi laba sebelum pajak, sedangkan menurut UU PPh pasal 9 ayat 1 (c) Tahun 2013, cadangan kerugian piutang tidak dapat dijadikan pengurang penghasilan kena pajak kecuali perusahaan yang memiliki tingkat resiko tinggi.

Ukuran perusahaan menghasilkan nilai signifikan 0,000, dimana nilai tersebut lebih kecil dari 0,05 yang menggambarkan bahwa ukuran perusahaan berpengaruh terhadap book tax gap pada perusahaan yang terdaftar di Bursa Efek Indonesia tahun 2014-2018, hal ini karena semakin besar ukuran perusahaan, akan semakin baik perusahaan dalam melakukan tax planning. Tax planning adalah upaya wajib pajak untuk meminimalkan pajak yang terutang melalui skema yang memang jelas diatur dalam peraturan perundang-undangan perpajakan dan sifatnya tidak menimbulkan dispute antara wajib pajak dan otoritas pajak,. Apabila perusahaan melakukan tax planning maka penghasilan kena pajak akan kecil dibandingkan dengan laba sebelum pajak.

Leverage menghasilkan nilai signifikan 0,000 , dimana nilai tersebut lebih kecil dari 0,05 yang menggambarkan bahwa leverage terhadap book tax gap pada perusahaan yang terdaftar di Bursa Efek Indonesia tahun 2014-2018, hal ini karena leverage merupakan rasio yang menunjukkan seberapa banyak perusahaan menggunakan utang untuk membiayai investasinya. Perusahaan yang memilih pembiayaan utang bukan pembiayaan ekuitas untuk membiayai kegiatan operasinya akan memiliki book tax gap yang rendah dibandingkan dengan pembiayaan ekuitas. Hal ini karena efek bunga yang berasal dari pembiayaan utang tidak dapat dikurangkan dari penghasilan kena pajak.

Kompensasi kerugian menghasilkan nilai signifikan 0,044, dimana nilai tersebut lebih kecil dari 0,05 yang menggambarkan bahwa kompensasi kerugian terhadap book tax gap pada perusahaan yang terdaftar di Bursa Efek Indonesia tahun 2014-2018, hal ini karena kompensasi kerugian yang dimanfaatkan pada satu periode mengurangi penghasilan kena pajak sehingga selisih penghasilan kena pajak dengan laba akuntansi akan semakin besar 


\section{DAFTAR PUSTAKA}

Bursa Efek Indonesia. (2019). Aktivitas dan Profil Perusahaan. Melalui http://www.idx.co.id. Tanggal akses 15 November - 10 Januari 2020.

Carolus Askikarno Palalangan, Ribka Pakendek, \& Luther P. Tangdialla. (2019). PENGARUH PERSEPSI WAJIB PAJAK TENTANG PENERAPAN PP NO 23 TAHUN 2018, PEMAHAMAN PERPAJAKAN DAN SANKSI PERPAJAKAN TERHADAP KEPATUHAN WAJIB PAJAK UMKM DI MAKASSAR. Paulus Journal of Accounting (PJA), 1(1), 29-41. https://doi.org/10.34207/pja.v1i1.27

Irfan, Fatkhur Haris dan Endang Kiswara. (2013). Pengaruh Laba Akuntansi dan Laba Fiskal terhadap Persistensi Laba dengan Komponen Akrual dan Aliran Kas sebagai Variabel Moderasi (Studi Empiris pada Perusahaan Manufaktur yang Terdaftar di Bursa Efek Indonesia 2008-2011). Diponegoro Journal of Accounting. Volume 2, Nomor 2, Tahun 2013, halaman 1-13 ISSN (Online): 2337-3806.

Martani et.al. 2011. Book-Tax Gap: Evidence from Indonesia.China-USA Business Review. 10 (4): 278-284

Persada, Aulia Eka dan Dwi Martani. (2010). Analisis Faktor Yang Mempengaruhi Book Tax Gap Dan Pengaruhnya Terhadap Persistensi Laba. Jurnal Akuntansi dan Keuangan Indonesia Vol 7 (2): 205-221.

Riansa, Ikhsan dan Rahmawaty. (2017). Pengaruh Profitabilitas, Tingkat Hutang, Dan Ukuran Perusahaan Terhadap Book Tax Gap pada Perusahaan Sub-Sektor Property Dan Real Estate Yang Terdaftar Di Bursa Efek Indonesia Tahun 20122015. Jurnal Ilmiah Mahasiswa Ekonomi Akuntansi (JIMEKA) Vol. 2, No. 4, (2017) Halaman 52-66 E-ISSN 2581-1002.

Sugiyono. (2011). Metode penelitian kombinasi (mixed methods). Bandung: Alfabeta.

Winarsih, Yuli. 2015. Pengaruh Pertumbuhan Pendapatan, Asset Tetap, Kompensasi Kerugian, Ukuran Perusahaan, dan Leverage terhadap Book Tax Gap. Skripsi. Universitas Muhammadiyah Purwokerto.

Yasnita, Deni. 2014. Pengaruh Perbedaan Laba Akuntansi dan Laba Fiskal, Volatilitas Arus Kas, Volatilitas Penjualan, Aliran Kas Operasi Dan Komponen Akrual Terhadap Persistensi Laba(Studi Empiris Pada Perusahaan Manufaktur Yang Terdaftar Dalam Index Saham Syariah Indonesia (ISSI) Tahun 2011-2015). Skripsi. Institut Agama Islam Negeri Surakarta. 